Volume: 11 Issue: 2 Year: 2014

\title{
The relationship between in-service training nurses' attitudes toward computer in health care and computer anxiety in Turkey
}

\author{
Hülya Kaya ${ }^{2}$ \\ Burçin Işık ${ }^{3}$ \\ Gönül Bodur ${ }^{4}$
}

\begin{abstract}
Nurses' perception relating to using technology and computer can directly affect how they structure in-service and continuous education programmes. This research was planned as a crosssectional-correlational design to determine the relationship between in-service training nurses' attitudes toward computer in health care and computer anxiety. Research was realized with 116 inservice training nurses who work at Education Department of Istanbul Local Health Authority and primary, secondary and tertiary health institution subordinate Istanbul Local Health Authority. Data were collected after getting permission from Istanbul Local Health Authority considering voluntariness with "Personal Information Form", "Attitudes Toward Computer in Health Care Assessment Scale (P.A.T.C.H. Assesment Scale)" and "Computer Anxiety Scale (CAS)". Research data were analyzed with SPSS package program. Mean of the P.A.T.C.H. Assesment Scale was found as $20.07 \pm 11.91$, mean of the CAS was found as $39.31 \pm 9.52$. There is a moderate negatively significant correlation between the attitude of the in-service training nurses toward computer in health care and their computer anxiety ( $\mathrm{r}:-0.502 \mathrm{p} \leq 0.01)$. The results of research are limited to in-service training nurses who work in Istanbul and are not generalized to all in-service training nurses. The research findings suggest that in-service training nurses have positive attitude toward computer in health care and low computer anxiety. These findings will enable in-service training nurses to consider the importance of using technology and computer. Understanding these concepts is beneficial in efforts to improve the educational activities offered to nurses, other medical staff and patients.
\end{abstract}

Keywords: Nurse; In-service training nurse; Health care; Computer anxiety; Turkey

\footnotetext{
1 This research presented in the International Educational Technology Conference, 2010 as oral notice.

2 Assoc. Prof., Istanbul University, Florence Nightingale Nursing Faculty, Nursing Education Department, Turkey, hulyakay@istanbul.edu.tr

3 Assist. Prof., Zirve University, Faculty of Health Sciences, Nursing Department, Turkey, burcin.isik@,zirve.edu.tr

${ }^{4}$ Res. Assist. M.Sc.,, Istanbul University, Florence Nightingale Nursing Faculty, Nursing Education Department,

Turkey, gnlbodur@,istanbul.edu.tr
} 
Kaya, H., Işı1k, B., \& Bodur, G. (2014). The relationship between in-service training nurses' attitudes toward computer in health care and computer anxiety in Turkey. International Journal of Human Sciences, 11(2), 948-963. doi: $\underline{10.14687 / \text { ijhs.v11i2.2712 }}$

\section{Introduction}

Fast and surprising advancements in science and technology have deep impact on professional life, and play a significant role in rendering the service provided more effective and efficient (Kısa\&Kaya, 2006; Meral\&Çolak, 2002). Information technology applications in health professional education, research and clinical practice are an increasingly important aspect in healthcare organizations (Koivunen et al., 2008; Oroviogoicoechea et al., 2010). As a result of such advancements, more and more computers are being used in the fields of health and education becomes inevitable (Jiang et al., 2004; Erdemir et al., 2005). Besides producing, processing, storing, distributing and using information, the computers increase the level of learning by simultaneously addressing several senses, create permanent learning, save from time, place and learning speed and support life-long learning. With such attributes, the computers support efficient fulfillment of the roles, functions and responsibilities of the nurses/in-service training nurses, increase the quality of health care and enhance quality and efficiency of nursing practice (McNeil et al., 2003; Jiang et al., 2004; Kaya et al., 2008; Lee, 2008; ANCC, 2010; Chow et al., 2011; Kaya, 2011; Lin et al., 2014). Nursing is not only a care giving profession, but has become a technology-proficient profession as well (Lee, 2008). In this context, Staggers et al. (2002) produced a research based master list of informatics competencies for nurses of four levels: beginning nurses, experienced nurses, informatics specialists, and informatics innovators.

However, successful implementation of the computer and computer systems depends mainly on the nurses' /in-service training nurses' attitudes its use and acceptance (Oroviogoicoechea et al., 2010; Chow et al., 2011). So, user attitudes are viewed as the components influencing the user technology adoption level and have been found critical to successful computer and computer system implementation (McLane, 2005).

Today, in-service training nurses' knowledge, skill and attitude about changing/advancing computer and computer systems become too important to realize educational activities in accordance with teaching-learning process (Gül et al., 2003; Kaya\&Așt, 2008). In this respect, nursing organizations emphasize knowledge, skill and attitude regarding the usage of computer and computer systems as effective in nursing as a desirable attribute. United Kingdom Central CouncilUKCC, define some technological skills such as using computer as a key skill which nurses should have (Wishart\&Ward, 2002). United Kingdom National Health Service Information Authority suggests to be asked for European Computer Usage Licence as a basic competence for nurses (Wishart\&Ward, 2002). American Nurses Association-ANA (2001) emphasize the nurses should be computer-literate and have detailed informatics competence (McNeil et al., 2003). Also, the 2010 
Kaya, H., Işı1k, B., \& Bodur, G. (2014). The relationship between in-service training nurses' attitudes toward computer in health care and computer anxiety in Turkey. International Journal of Human Sciences, 11(2), 948-963. doi: 10.14687/ijhs.v11i2.2712

Institute of Medicine report titled, “The Future of Nursing: Leading Change, Advancing Health,” identified technology as the means toward both increased patient safety and cost-efficient care, citing nurses as having a "fundamental role" in this technology transformation.

When early works were examined, it was seen that emphasized nurses need appropriate knowledge and skills to use computers. Bryson (1991) emphasizes that in order for the nurses to be computer-literate; they should have basic computer knowledge, and know how they can develop their professional skills through computer and how to benefit from computer as a tool in nursing practices. Carter and Axford (1993) identified computer learning needs of practicing nurses at the bedside. In the literature, it is emphasized that nurses' attitudes toward computer and anxiety is effective to use computer in professional practice (Wishart\&Ward, 2002; McNeil et al., 2003; Jiang et al., 2004; NHS, 2010). When the definitions of anxiety are examined; it is expressed as "sadness, thoughts creating uneasiness, worry" (Turkish Linguistic Society, 2006); and defined as "an emotion distinguished from other emotions with anxiety, depression, and unpleasant characteristics" (Arkonaç, 1999). Computer anxiety is disscussed as one of the factors that comprise attitudes regarding computer and defined to be indisposition to inreact with computer or use computer and widely experienced by many adults (Ceyhan\&Namlu, 2000; Namlu\&Ceyhan, 2003; Özbıçakçı et al., 2011).

In 16. item's a,b,c paragraph of In-Service Training Regulation numbered 15296 of The Ministry of Health of Turkey it is intended to develop and increase health care employees' knowledge and qualifications (The Ministry of Health of Turkey, 2010). In this context, it can be said that in-service training nurses have a key role to raise the qualification of health care, and it is a necessity to have positive attitude, knowledge and skill directed computer to actualize these roles as effective and productive. It shouldn't be forgotten that computer anxiety becomes effective to gain this qualification. In the light of this explanations in this research it is aimed to identify in-service training nurses' attitudes toward computer in health care and computer anxiety. It is thought the results will be beneficial to restructure the continuous education programmes accordingly intended nurses.

\section{Purpose}

This research was conducted to determine the relationship between in-service training nurses' attitudes toward computer in health care and computer anxiety. In accordance with this aim following questions guided this study: 
Kaya, H., Işık, B., \& Bodur, G. (2014). The relationship between in-service training nurses' attitudes toward computer in health care and computer anxiety in Turkey. International Journal of Human Sciences, 11(2), 948-963. doi: $\underline{10.14687 / \text { ijhs.v11i2.2712 }}$

- How is in-service training nurses' attitudes toward computer in health care?

- Do in-service training nurses have computer anxiety?

- Is there any relationship between in-service training nurses' attitudes toward computer in health care and computer anxiety?

- Do in-service training nurses' attitudes toward computer and computer anxiety differ from in terms of in-service training nurses' some identifications?

\section{Method and material}

\subsection{Population and sample selection}

The universe of research was included 137 in-service training nurses who work at Education Department of Istanbul Local Health Authority and primary, secondary and tertiary health institution subordinate Istanbul Local Health Authority. All of universe participated research and it was realized with 116 in-service training nurses. One survey form didn't be evaluated because of filling out a survey incorrect, and didn't be reached twenty in-service training nurses who are on leave/on sick leave. Participation rate of study was $85 \%$.

\subsection{Type of study}

This study was conducted as a cross-sectional-correlational design.

\subsection{Data collection}

In research, "Personal Information Form", "Attitudes Toward Computer in Health Care Assessment Scale (P.A.T.C.H. Assesment Scale)" and "Computer Anxiety Scale (CAS)" was used as data collection tool.

Personal Information Form is included in-service training nurses' age, sex, marital status, graduate of educational programme, work year as an in-service training nurse, have own computer, computer usage, self-assessment at using computer, computer usage in educational activities and, whether the participate computer education.

Attitudes Toward Computer in Health Care Assessment Scale (P.A.T.C.H. Assesment Scale) was used to determine in-service training nurses' attitudes toward computer in health care. The scale was developed by Kaminski in 1996 and produced $2^{\text {nd }}$ version in 2007, and was made validity and realibility by Kaya and Aşt1 in 2008 and found cronbach alpha value as .90. Also, in our study cronbach alpha value was found as .94. The scale is five point likert scale with answer options from 
Kaya, H., Işık, B., \& Bodur, G. (2014). The relationship between in-service training nurses' attitudes toward computer in health care and computer anxiety in Turkey. International Journal of Human Sciences, 11(2), 948-963. doi: 10.14687/ijhs.v11i2.2712

"strongly agree", to "strongly disagree" and constituted 40 questions. Scale score interval changes between -40 and 40 . Score is getting closer to 40, attitude increase positively (Kaya\&Așt1, 2008).

Computer Anxiety Scale (CAS) was used to determine in-service training nurses' computer anxiety. The scale was developed by Ceyhan and Namlu in 2000 and was made validity and realibility and found cronbach alpha value as .94 also, in our study cronbach alpha value was found as .92. The scale is four point likert scale with answer options as "never" (1), "sometimes" (2), "often" (3), "always" (4) and constituted 28 items. Scale score interval is between 28-112. Four items in scale were marked reverse. It is showed that when scale point increases, computer anxiety increases, too (Ceyhan\&Namlu, 2000).

Each in-service training nurses were given data collection forms. The data were collected by means of a personal interview after getting written and oral permission. Data collection took 15 minutes.

\subsection{Limitations of the study}

The results of research are limited to in-service training nurses who work in Istanbul and are not generalized to all in-service training nurses.

\subsection{Research ethics}

Data were collected after getting permission from Istanbul Local Health Authority considering voluntariness. Participants were informed of the purpose and procedure of the study. Oral and written consents were obtained from the informants.

\subsection{Evaluation of data}

Research data were analyzed with SPSS (Version:17.0) package program by descriptive statistics as frequency-percentage, mean, standard deviation, t-test for identifying differences between groups, One-Way ANOVA, Tukey HSD to determine the source of the difference and correlation analysis to determine the relationship between variables and significance level was set as .05 (Özdamar, 2001; Bahar, 2004; Akgül, 2005). 
Kaya, H., Işı1k, B., \& Bodur, G. (2014). The relationship between in-service training nurses' attitudes toward computer in health care and computer anxiety in Turkey. International Journal of Human Sciences, 11(2), 948-963. doi: $\underline{10.14687 / \text { ijhs.v11i2.2712 }}$

\section{Results}

Identifications of In-Service Training Nurses

Table 1: In-service training nurses' identifications (N: 116)

\begin{tabular}{|c|c|c|}
\hline Identifications & $\mathrm{n}$ & $\%$ \\
\hline \multicolumn{3}{|l|}{ Age } \\
\hline $20-29$ & 29 & 25.0 \\
\hline $30-39$ & 64 & 55.2 \\
\hline$\geq 40$ & 23 & 19.8 \\
\hline \multicolumn{3}{|l|}{ Sex } \\
\hline Female & 112 & 96.6 \\
\hline Male & 4 & 3.4 \\
\hline \multicolumn{3}{|l|}{ Marital Status } \\
\hline Married & 89 & 76.7 \\
\hline Single & 27 & 23.3 \\
\hline \multicolumn{3}{|c|}{ Graduate of Educational Program } \\
\hline Health vocational high schools & 7 & 6.0 \\
\hline Associate degree & 45 & 38.8 \\
\hline Undergraduate degree & 37 & 31.9 \\
\hline Graduate degree & 27 & 23.3 \\
\hline \multicolumn{3}{|l|}{ Work Month } \\
\hline $0-23$ month & 50 & 43.1 \\
\hline 24-59 month & 29 & 25.0 \\
\hline 60-119 month & 20 & 17.2 \\
\hline$\geq 120$ month & 17 & 14.7 \\
\hline \multicolumn{3}{|l|}{ Have Own Computer } \\
\hline Yes & 112 & 96.6 \\
\hline No & 4 & 3.4 \\
\hline \multicolumn{3}{|l|}{ Computer Usage } \\
\hline Yes & 116 & 100.0 \\
\hline No & 0 & 0 \\
\hline \multicolumn{3}{|c|}{ Self-Assessment at Using Computer } \\
\hline Perfect & 12 & 10.3 \\
\hline Good & 99 & 85.3 \\
\hline $\mathrm{Bad}$ & 5 & 4.4 \\
\hline \multicolumn{3}{|c|}{ Computer Usage in Educational Activities } \\
\hline Yes & 116 & 100.0 \\
\hline No & 0 & 0 \\
\hline \multicolumn{3}{|c|}{ Participate Computer Education* } \\
\hline Yes & 88 & 80.7 \\
\hline No & 21 & 19.3 \\
\hline
\end{tabular}

*7 people didn't answer this question

As shown in Table 1, out of the in-service training nurses, $55.2 \%$ were between the ages of 30-39, 96.6\% were female, $76.7 \%$ were married, 38.8\% had associate degree, $31.9 \%$ had undergraduate degree, $43.1 \%$ had been working for $0-23$ month, $96.6 \%$ had their own computers, $100 \%$ used computer, and $85.3 \%$ assessed themselves as good at using computers. 
Kaya, H., Işık, B., \& Bodur, G. (2014). The relationship between in-service training nurses' attitudes toward computer in health care and computer anxiety in Turkey. International Journal of Human Sciences, 11(2), 948-963. doi: $\underline{10.14687 / \text { ijhs.v11i2.2712 }}$

It was determined that $100 \%$ of the in-service training nurses used computers in educational activities, $80.7 \%$ had participated computer education, and $52.3 \%$ of the participants found the duration and quality of the education program insufficient, and $71.4 \%$ out of those who had not participated in a computer education were eager to receive education about computer use.

Table 2: In-service training nurses' computer usage in educational process stages (N: 116)

\begin{tabular}{lcc}
\hline Stages** & Yes & No \\
& $\mathbf{n ~ ( \% )}$ & $\mathbf{n}(\mathbf{\%})$ \\
Collecting Data for Educational Requirements* & $94(86.2)$ & $15(13.8)$ \\
Planning Education Programme* & $106(97.2)$ & $3(2.8)$ \\
Implementing Education Programme* & $101(92.6)$ & $8(7.4)$ \\
Assessing Education Programme* & $94(86.2)$ & $15(13.8)$ \\
Recording/Reporting Education Programme* & $102(93.6)$ & $7(6.4)$ \\
Other & $19(16.4)$ & $97(83.6)$ \\
\hline
\end{tabular}

\section{* 7 people didn't answer this question.}

** Marked more than one option.

As shown in Table 2, at the educational process stages, out of the in-service training nurses, $86.2 \%$ used the computer for collecting data for educational requirements, $97.2 \%$ for planning the education programme, $92.6 \%$ for implementing the education programme, $86.2 \%$ for assessing the education programme, $93.6 \%$ for recording/reporting the education programme, $16.4 \%$ for research, execution of the quality studies and communicating with other professionals.

\section{In-Service Training Nurses' Attitudes Towards Computer in Health Care and Computer Anxiety}

Table 3: In-service training nurses' attitudes toward computer in health care and computer anxiety means and standard deviations (N: 116)

\begin{tabular}{lcc} 
& $\overline{\mathbf{X}}$ & SD \\
Attitudes Toward Computer in Health Care & 20.07 & 11.91 \\
Computer Anxiety & 39.31 & 9.52 \\
\hline
\end{tabular}

As shown in Table 3, mean of the P.A.T.C.H. Assesment Scale of the in-service training nurses was $20.07 \pm 11.91$. The mean of CAS of the in-service training nurses was found to be $39.31 \pm 9.52$. 
Kaya, H., Işı1k, B., \& Bodur, G. (2014). The relationship between in-service training nurses' attitudes toward computer in health care and computer anxiety in Turkey. International Journal of Human Sciences, 11(2), 948-963. doi: $\underline{10.14687 / \text { ijhs.v11i2.2712 }}$

Table 4: Comparison of in-service training nurses' attitudes toward computer in health care and computer anxiety according to identifications (N:116)

\begin{tabular}{|c|c|c|c|c|}
\hline \multirow[t]{2}{*}{ Tdentifications } & & $n$ & Computer Anxiety & $\begin{array}{c}\text { Attitudes T oward Computer } \\
\text { in H ealth Care }\end{array}$ \\
\hline & & & $\overline{X \pm S D}$ & $X \pm S D$ \\
\hline \multirow[t]{4}{*}{ Age } & $20-29$ & 29 & $38.72 \pm 7.30$ & $23.68 \pm 9.90$ \\
\hline & $30-39$ & 64 & $39.45 \pm 10.49$ & $20.69 \pm 11.47$ \\
\hline & 40 & 23 & $39.65 \pm 9.48$ & $11.73 \pm 15.15$ \\
\hline & & & F: $0.076 \quad$ p: 0.927 & F: 9.960 p: $\mathbf{0 . 0 0 1}^{* *}$ \\
\hline \multirow{5}{*}{$\begin{array}{l}\text { Graduate of } \\
\text { Educational } \\
\text { Programme }\end{array}$} & $\begin{array}{l}\text { Health vocational } \\
\text { high schools }\end{array}$ & 7 & $39.71 \pm 8.59$ & $13.85 \pm 18.36$ \\
\hline & Associate degree & 45 & $40.95 \pm 11.47$ & $19.10 \pm 11.70$ \\
\hline & $\begin{array}{l}\text { Undergraduate } \\
\text { degree }\end{array}$ & 37 & $38.64 \pm 8.41$ & $18.74 \pm 13.60$ \\
\hline & Graduate degree & 27 & $37.37 \pm 7.31$ & $23.38 \pm 10.20$ \\
\hline & & & $F: 0.883 \quad$ p: 0.453 & F: $1.407 \quad$ p: 0.245 \\
\hline \multirow{5}{*}{ Work Month } & $0-23$ month & 50 & $39.60 \pm 8.31$ & $19.96 \pm 11.48$ \\
\hline & 24-59 month & 29 & $41.89 \pm 11.31$ & $19.82 \pm 11.73$ \\
\hline & 60-119 month & 20 & $36.45 \pm 8.00$ & $19.95 \pm 15.29$ \\
\hline & $\geq 120$ month & 17 & $37.41 \pm 10.63$ & $18.20 \pm 14.28$ \\
\hline & & & F: 1.579 p: 0.198 & $F: 0.089 \quad p: 0.966$ \\
\hline \multirow{4}{*}{$\begin{array}{l}\text { Self-Assessment } \\
\text { at Using } \\
\text { Computer }\end{array}$} & Perfect & 12 & $30.33 \pm 2.10$ & $29.70 \pm 7.88$ \\
\hline & Good & 99 & $39.63 \pm 8.90$ & $18.97 \pm 12.56$ \\
\hline & $\mathrm{Bad}$ & 5 & $54.40 \pm 11.14$ & $9.30 \pm 5.79$ \\
\hline & & & $\mathrm{F}: 14.389 \mathrm{p}: \mathbf{0 . 0 0 0 ^ { * * }}$ & F: 6.228 p: $\mathbf{0 . 0 0 3 ^ { \star * * }}$ \\
\hline \multirow{3}{*}{$\begin{array}{l}\text { Participate } \\
\text { Computer } \\
\text { Education }\end{array}$} & Yes & 88 & $38.96 \pm 9.05$ & $20.62 \pm 11.61$ \\
\hline & No & 21 & $40.23 \pm 11.84$ & $16.71 \pm 16.97$ \\
\hline & & & $\mathrm{t}: 0.544 \quad \mathrm{p}: 0.588$ & $\mathrm{t}: 1.001 \quad \mathrm{p}: 0.326$ \\
\hline \multirow{4}{*}{$\begin{array}{l}\text { Whether The } \\
\text { Participants of } \\
\text { The Computer } \\
\text { Education } \\
\text { Found The } \\
\text { Duration And } \\
\text { Quality of The } \\
\text { Education } \\
\text { Sufficient }\end{array}$} & Yes & 42 & $35.92 \pm 6.24$ & $23.54 \pm 10.15$ \\
\hline & & & 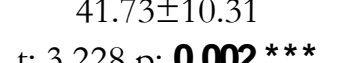 & t. 2312 n. $0.023^{\star * \star *}$ \\
\hline & & & t: $5 . \angle 20$ p: $\mathbf{U} . \mathbf{0} \mathbf{2}$ & p: $\mathbf{0 . 0 < 0}$ \\
\hline & & & & \\
\hline
\end{tabular}

* 7 people didn't answer this question.

$* * \mathrm{p} \leq 0.001 \quad * * * \mathrm{p}<0.01 \quad * * * * \mathrm{p}<0.05$

As shown in Table 4, the highest average of CAS points was among the age group of 40 and over (39.65 \pm 9.48$)$. There was no statistically significant difference between the average of CAS points of the in-service training nurses according to their ages $(\mathrm{p}>0.05)$. The highest average of 
Kaya, H., Işı1k, B., \& Bodur, G. (2014). The relationship between in-service training nurses' attitudes toward computer in health care and computer anxiety in Turkey. International Journal of Human Sciences, 11(2), 948-963. doi: $\underline{10.14687 / \text { ijhs.v11i2.2712 }}$

P.A.T.C.H. Assesment Scale points was among the age group of 20-29 (23.68 \pm 9.90$)$. There was a high statistically significant difference between the average P.A.T.C.H. Assesment Scale points of the in-service training nurses according to their ages $(\mathrm{p} \leq 0.001)$. It was determined that such difference resulted from the age groups of 20-29 and 30-39.

When the average CAS points of the in-service training nurses were examined according to the educational programme they had graduated from, the highest average was among the associate degree holders (40.95 \pm 11.47$)$. There was no statistically significant difference between the average CAS points of the in-service training nurses according to the educational programmes they had graduated from $(\mathrm{p}>0.05)$. When the average P.A.T.C.H. Assesment Scale points of the in-service training nurses were examined according to the educational programme they had graduated from, the highest average was among the graduate degree holders $(23.38 \pm 10.20)$. There was no statistically significant difference between the average P.A.T.C.H. Assesment Scale points of the inservice training nurses according to the educational programmes they graduated from $(\mathrm{p}>0.05)$.

When the average CAS points of the in-service training nurses were examined according to

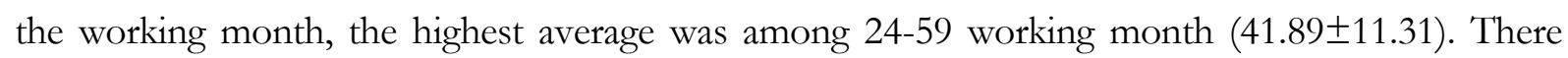
was no statistically significant difference between the average CAS points of the in-service training nurses according to their working month ( $>>0.05)$. When the average P.A.T.C.H. Assesment Scale points of the in-service training nurses were examined according to the working month, the highest

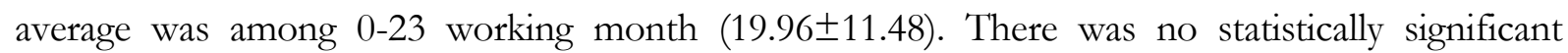
difference between the average P.A.T.C.H. Assesment Scale points of the in-service training nurses according to their working month $(\mathrm{p}>0.05)$.

When the average CAS points of the in-service training nurses were examined according to their self-assessment at using computer, the highest average was among those who regard

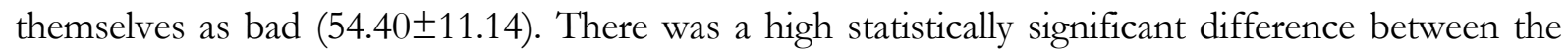
average CAS points of the in-service training nurses according to their self-assessment regarding computer use $(\mathrm{p} \leq 0.001)$. This difference was found to be resulted from those who regarded themselves as perfect and good. When the average P.A.T.C.H. Assesment Scale points of the inservice training nurses were examined according to their self-assessment at using computer, the highest average was among those who regard themselves as perfect (29.70 \pm 7.88$)$. There was a high statistically significant difference between the average P.A.T.C.H. Assesment Scale points of the inservice training nurses according to their self-assessment regarding computer use $(\mathrm{p}<0.01)$. This difference was found to be resulted from those who regarded themselves as perfect. 
Kaya, H., Işık, B., \& Bodur, G. (2014). The relationship between in-service training nurses' attitudes toward computer in health care and computer anxiety in Turkey. International Journal of Human Sciences, 11(2), 948-963. doi: $\underline{10.14687 / \text { ijhs.v11i2.2712 }}$

When the average CAS points of the in-service training nurses were examined according to their participation in a computer education, the highest average was among the non-participants (40.23 \pm 11.84$)$. There was no statistically significant difference between the average CAS points of the in-service training nurses according to their participation in a computer education $(p>0.05)$. When the average P.A.T.C.H. Assesment Scale points of the in-service training nurses were examined according to their participation in a computer education, the highest average was among the participants (20.62 \pm 11.61$)$. There was no statistically significant difference between the average P.A.T.C.H. Assesment Scale points of the in-service training nurses according to their participation in a computer education $(\mathrm{p}>0.05)$.

When the average CAS points of the in-service training nurses were examined according to whether the participants of the computer education found the duration and quality of the education sufficient, the highest average was among those who found it insufficient (41.73 \pm 10.31$)$. There was a high statistically significant difference between the average CAS points of the in-service training nurses according to whether they found the duration and quality of the education sufficient $(\mathrm{p}<0.01)$. When the average P.A.T.C.H. Assesment Scale points of the in-service training nurses were examined according to whether the participants of the computer education found the duration and quality of the education sufficient, the highest average was among those who found it insufficient (23.54 \pm 10.15$)$. There was a statistically significant difference between the average P.A.T.C.H. Assesment Scale points of the in-service training nurses according to whether they found the duration and quality of the education sufficient $(\mathrm{p} \leq 0.05)$.

Table 5: Correlation between in-service training nurses' attitudes toward computer in health care and computer anxiety

\begin{tabular}{lccc}
\hline & & Computer Anxiety & $\begin{array}{c}\text { Attitudes Toward Computer in } \\
\text { Computer Anxiety }\end{array}$ \\
& $\mathrm{r}$ & 1.000 & $-0.502^{*}$ \\
Attitudes Toward Computer in & $\mathrm{p}$ & - & 0.000 \\
Health Care & $\mathrm{r}$ & $-0.502^{*}$ & 1.000 \\
& $\mathrm{p}$ & 0.000 & - \\
\hline
\end{tabular}

$* \mathrm{p}<0,001$

When Table 5 is examined, there is a moderate negatively significant correlation between the attitude of the in-service training nurses toward computer in health care and their computer anxiety (r: $-0.502 \quad \mathrm{p}<0.01)$. 
Kaya, H., Işı1k, B., \& Bodur, G. (2014). The relationship between in-service training nurses' attitudes toward computer in health care and computer anxiety in Turkey. International Journal of Human Sciences, 11(2), 948-963. doi: $\underline{10.14687 / \text { ijhs.v11i2.2712 }}$

\section{Discussion}

The results of the study demonstrated that most of the in-service training nurses used computer in educational activities and participated in a computer education. The findings were in parallel with the results of the study conducted by June et al. (2000) in China with 169 nurses which showed that $56.2 \%$ of the nurses participated in a computer-related education programme, and the results of the study conducted by Eley et al. (2009) in Australia which demonstrated that $86.3 \%$ of the nurses used computer in their activities. The findings were also similar to the results of the studies conducted by Koç (2003), Erdemir et al. (2005), and Cragg et al. (2003). The results demonstrated that in-service training nurses were open to development in this area.

The results showed that the in-service training nurses utilized computers at every stages of educational process, and particularly at planning education programme stage. This result was in parallel with the results of the studies conducted by Atay et al. (2009) and Başar et al. (2008) which demonstrated that most of the nurses utilized computers in the educational process, particularly in collecting data for educational requirements and planning education programme.

In this study it is determined that in-service training nurses' attitudes toward computer in health care is high, and computer anxiety is lower. In 16. item's c paragraph of In-Service Training Regulation numbered 15296 of The Ministry of Health of Turkey it is identified that in-service training nurses should use effective, useful and advanced educational techniques/technologies in education. This result in the direction of regulation can be considered as positive in realizing inservice training nurses' duty, power and responsibilities. In literature, it is emphasized that when anxiety decreases, increase learning willingness, get easy learning, effect learning readiness and consequently attitude. In-service training nurses' anxiety is low can be considered as a positive result in terms of having positive attitude, using computer and self-development (Ceyhan\&Namlu, 2000; Kurt, 2000; Namlu\&Ceyhan, 2003; Taşocak, 2012; Bacanl1, 2009).

The study demonstrated that in-service training nurses under 40 years of age had lower computer anxiety and more positive attitudes toward computers in health care. This was in line with the findings of the study conducted by Moody et al. (2004) in Florida with 100 nurses showing that there was a negative correlation between age and attitude toward computers $(\mathrm{r}:-0.24)(\mathrm{p}=0.01)$. This result was also similar to the results of the studies conducted by Burkes (1991), Koç (2003), June et al. (2000), Cragg et al. (2003), Eley et al. (2009) and Oroviogoicoechea and Watson (2009). This result was consistent with the literature which suggested that younger groups were more eager to use computers, and therefore had less anxiety (Çevik\&Baloğlu, 2007). 
Kaya, H., Işı1k, B., \& Bodur, G. (2014). The relationship between in-service training nurses' attitudes toward computer in health care and computer anxiety in Turkey. International Journal of Human Sciences, 11(2), 948-963. doi: $10.14687 /$ ijhs.v11i2.2712

The study results made us think that the educational programme the in-service training nurses had graduated from didn't effect computer anxiety and attitude toward computers in health care.

The study results made us think that working month of the in-service training nurses didn't effect computer anxiety and attitude toward computer in health care. This result was similar to the results of the studies conducted by Marasovic et al. (1997) and Moody et al. (2004) which showed that there was no significant correlation between the working month of the nurses and their attitude toward computer.

Another result of the study was that self-assessment of the in-service training nurses effected the attitude toward computer in health care and computer anxiety. This result was in parallel with the results of the studies conducted by Namlu and Ceyhan (2003), Moody et al. (2004) and Oroviogoicoechea and Watson (2009). This made us think that anxiety and attitudes of the nurses with more experience in computers and who found themselves competent regarding the computers were positively effected.

The study revealed that participation in a computer education by the in-service training nurses didn't effect computer anxiety and attitude toward computer in health care, and this made us think that the content of such programmes should be questioned.

The study also showed that whether the in-service training nurses participating in a computer education found the duration and quality of the program sufficient didn't effect their computer anxiety and attitudes toward computer in health care. When the general averages are examined, it can be said that quality educational programmes addressing the computer-related requirements decrease the computer anxiety and positively effect the attitudes toward computer in health care.

In this study, there is moderate negative significant relationship between in-service training nurses' attitudes toward computer in health care and computer anxiety. This finding was in parallel with the study carried out by Koç (2003). This result show that in-service training nurses' computer anxiety decreases, positive attitudes toward computer in health care increases. In literature, it is emphasized when anxiety decreases, attitudes increase as positive. This result is parallel with literature (Ceyhan\&Namlu, 2000; Kurt, 2000; Namlu\&Ceyhan, 2003; Taşocak, 2012; Bacanl1, 2009).

This study was carried out to identify in-service training nurses attitudes toward computer in health care and computer anxiety. The results of the research showed that in-service training nurses have a positive attitude toward computer in health care and lower computer anxiety. So, it was determined that the in-service training nurses were confident about their ability to use various 
Kaya, H., Işı1k, B., \& Bodur, G. (2014). The relationship between in-service training nurses' attitudes toward computer in health care and computer anxiety in Turkey. International Journal of Human Sciences, 11(2), 948-963. doi: 10.14687/ijhs.v11i2.2712

computer programmes, believed in the benefit of the computers in social development, had eager perspective for computer-use in health care. In-service training nurses' attitudes toward computer in health care were positively increasing while in-service training nurses' computer anxiety was decreasing. In-service training nurses' attitudes toward computer in health care were effected from age, self-assessment at using computer, whether the participants of the relevant education programme found the duration and quality of the education sufficient. Also, in-service training nurses' computer anxiety was effected from self-assessment at using computer, whether the participants of the relevant education programme found the duration and quality of the education sufficient.

\section{Conclusions and recommendations}

Our findings are able to provide guidance for in-service training nurses to understand the complex factors of computer technologies implementation, to address the in-service training nurses' needs. Successful implementation of the technology depends mainly on the in-service training nurses' attitudes and satisfaction with the use of the computer. In-service training nurses acceptance, feelings and satisfaction with the computer technologies would give a positive impact on in-service training nurses attitudes. This may directly improve educational activities realizing by in-service training nurse, and enhancing communication among departments. By understanding the issues that may be of concern to computer technology users, implementation strategies and policy requirements can be designed to support the in-service training nurses' needs in this technology adoption process.

According to research results will recommended;

- In-service training nurses' needs, ages, self-assessment, computer anxiety were regarded for configuration training programmes toward computer,

- More innovative workshops and courses should also be organised as an on-the-job training to help nurses/in-service training nurses maintain their motivation and professional competence.

- Making similar researches with nurse groups which works different areas (Intensive care, operating room etc.).

\subsection{Usability of study results}

The study findings provide preliminary insights on in-service training nurses' perception of computer and computer technologies in Turkey. Although this study examined the issues in a local context, it has provided valuable information for international and cross-cultural comparisons and 
Kaya, H., Işı1k, B., \& Bodur, G. (2014). The relationship between in-service training nurses' attitudes toward computer in health care and computer anxiety in Turkey. International Journal of Human Sciences, 11(2), 948-963. doi: $\underline{10.14687 / \text { ijhs.v11i2.2712 }}$

for especially nurses who directly related with in-service education. These findings will enable inservice training nurses to consider the importance of using technology and computer. Understanding these concepts is beneficial in efforts to improve the educational activities offered to nurses, other medical staff and patients. The indicative content of educational programmes should incorporate and adequately address the technological dimension of nursing services. Nurses should take the initiative in increasing their skills and knowledge of using computer technologies and give priority to reflection in and on their educational activities. Knowledge of the training and education needs of in-service training nurses with respect to information and computer knowledge will provide a platform for the development of appropriate policies in the institution. However, understanding the barriers and difficulties they encountered could maximize their technology use and improve both the nursing efficiency and the services quality.

\section{References}

Akgül, A. (2005). Statistical analysis technics: SPSS applications. 3rd edn., Ankara: Emek Press.

American Nurses Credentialing Center-ANCC. (2010). Informatics nursing. Retrieved from http://www.nursecredentialing.org/NurseSpecialties/Informatics.aspx

Arkonaç, O. (1999). Expositional dictionary of psychiatry. Istanbul: Nobel Medicine Press.

Atay, S., Gider, D., Karadere, G., Şenyüz, P. (2009). The views of nurses' who work in hospital toward in-service education. International Journal of Human Sciences, 6, 85-93. Retrieved from http://www.insanbilimleri.com

Bacanl, H. (2009). Educational psychology. 14th edn., Ankara: Asal Press.

Bahar, Z. (2004). Statistical methods in analyzing datas. In İ. Erefe (Ed.), Research in nursing: Principles, process and methods (pp. 189-249). 3rd edn., Ankara, HEMAR-GE Association Press.

Başar, A., Delice, S.T., İlhan, M. N., Ergün, M. A., Soncul, H. (2008). Usage of computer in nursing services-example of Gazi University Medicine Faculty of Hospital. Journal of Informatic Technologies, 1, 43-46.

Burkes, M. (1991). Identifying and relating nurses' attitudes toward computer use. Computers in Nursing, 9, 190-201.

Bryson, D. (1991). The computer-literate nurse. Computers in Nursing, 9, 100-107.

Carter, B. E., Axford, R. L. (1993). Assessment of computer learning needs and priorities of registered nurses practicing in hospitals. Computers in Nursing, 11, 122-126.

Ceyhan, E., Namlu Gürcan, A. (2000). Computer anxiety scale (CAS): Study about validity and reliability. Journal of Education Faculty of Anadolu University, 10, 77-93.

Chow, S., Chin, W. Y., Lee, H. Y., Leung, H. C., Tan, F. H. (2011). Nurses' perceptions and attitudes towards computerisation in a private hospital. Journal of Clinical Nursing, 21, 16851696.

Cragg, C. E., Edwards, N., Yue, Z., Lixin, S., Dao Hu1, Z. (2003). Integrating web-based technology into distance education for nurses in China. Computers, Informatics, Nursing, 21, 265-274.

Çevik, V., Baloğlu, M. (2007). Examining school head's computer anxiety levels in diverse variables. Educational Administration in Theory and Practice, 13, 547-568.

Eley, R., Soar, J., Buikstra, E., Fallon, T., Hegney, D. (2009). Attitudes of Australian nurses to information technology in the workplace. Computers, Informatics, Nursing, 27, 114-121. 
Kaya, H., Işı1k, B., \& Bodur, G. (2014). The relationship between in-service training nurses' attitudes toward computer in health care and computer anxiety in Turkey. International Journal of Human Sciences, 11(2), 948-963. doi: $10.14687 /$ ijhs.v11i2.2712

Erdemir, F., Hanoğlu, Z., Akman, A. (2005). Status of nurses to use computer and internet and the views about value of using computer in nursing. Proceedings of the II. National Medical Informatics Congress, 78-84.

Gül, A., Gençtürk, N., Bozkurt, G. (2003). Examining the frequency of using computer and internet among nurses. Proceedings of the II. International \& IX. National Nursing Congress, 472474.

Institute of Medicine. The future of nursing: Leading change, advancing health. http://boks.nap.edu/openbook.php?record_id=12956\&page=R1. Published 2010. Accessed May 14, 2014.

Jiang, W., Chen, W., Chen, Y. (2004). Important computer competencies for the nursing profession. Journal of Nursing Research, 12, 213-225.

June, L., Linchong, P., Zhuoren, L., Totsaporn, K. (2000). Computer knowledge, attitudes and skills of nurses in people's hospital of Beijig medical university. Computer in Nursing, 18, 197206.

Kaya, N., Aştı, T. (2008). Validity and reliability of turkish version of the pretest for attitudes toward computers in healthcare assessment scale. Journal of Istanbul University Florence Nightingale School of Nursing, 16, 24-32.

Kaya, N., Aşt1, T., Kaya, H., Kaçar Yeşiltepe, G. (2008). Views of nurses about computer usage. Journal of Istanbul University Florence Nightingale School of Nursing, 16, 83-89.

Kaya, N. (2011). Factors affecting nurses' attitudes toward computers in healthcare. Computers Informatics Nursing, 29, 121-129.

Kısa, B., Kaya, H. (2006). Nurse facultys' attitudes toward technology. The Turkish Online Journal of Educational Technology-TOJET, 5 (2), 77-83.

Koç, Z. (2003). The Determination of the Opinions and the Concerns Related to Nurses' Function on Computer Using and Effectiveness of Education. PhD diss., Marmara University Institute of Medical Sciences, Istanbul.

Koivunen, M., Valimaki, M., Koskinen, A., Staggers, N., Katajisto, J. (2008). The impact of individual factors on healthcare staff's computer use in psychiatric hospitals. Journal of Clinical Nursing, 18, 1141-1150.

Kurt, İ. (2000). Adult education. Ankara: Nobel Press.

Lee, T-T. (2008). Nursing information: Users' experiences of a system in Taiwan one year after its implementation. Journal of Clinical Nursing, 17, 763-771.

Lin, H-C., Hsu, M-H., Yang, C-W. (2014). The influences of computer system success and informatics competencies on organizational impact in nursing envoriments. Computers, Informatics, Nursing, 32, 90-99.

Moody, L. E., Slocumb, E., Berg, B., Jackson, D. (2004). Electronic health records documentation in nursing. Computers, Informatics, Nursing, 22, 337-344.

Marasovic, C., Kenny, C., Elliott, D., Sindhusake, D. (1997). Attitudes of Australian nurses toward the implementation of a clinical information system. Computer Nursing, 15, 91-98.

Meral, M., Çolak, E. (2002). Technology usage profile of Marmara University Technical Education Faculty. Proceedings of the II. International Education Technology Symposium, 419-431.

McLane, S. (2005). Designing an EMR planning process based on staff attitudes toward and opinions about computers in healthcare. Computers, Informatics, Nursing, 23, 85-92.

McNeil, J. B., Elfrink, L. V., Bickford, J. C., Pierce, T. S., Beyea, C.S., Averill, C., Klappenbach, C. (2003). Nursing information technology knowledge, skills, and preparation of student nurses, nursing faculty, and clinicians: A U.S. survey. Journal of Nursing Education, 42, 341349.

Namlu Gürcan, A., Ceyhan, E. (2003). Computer anxiety: A multifaceted survey on preservice teachers. Educatinal Sciences in Theory and Practice, 3, 401- 432. 
Kaya, H., Işık, B., \& Bodur, G. (2014). The relationship between in-service training nurses' attitudes toward computer in health care and computer anxiety in Turkey. International Journal of Human Sciences, 11(2), 948-963. doi: $\underline{10.14687 / \text { ijhs.v11i2.2712 }}$

Oroviogoicoecheai, C., Watson, R. (2009). A quantitative analysis of the impact of a computerised information system on nurses' clinical practice using a realistic evaluation framework. International Journal of Medical Informatics, 78, 839-849.

Oroviogoicoechea, C., Watson, R., Beortequi, E., Remirez, S. (2010). Nurses' perception of the use of computerised information systems in practice: Questionnare development. Journal of Clinical Nursing, 19, 240-248.

Özbıçakçı, Ş., Bektaş, M., Çetin, E., Uysal, N. (2011). Comparison of basic computer training strategies and their effects on the level of computer anxiety in Turkish nursing students. Computers, Informatics, Nursing, 29, 239-244.

Özdamar, K. (2001). Bioistatistics with SPSS. 4th edn., Eskişehir: Kaan Press.

Staggers, N., Gassert, C. A., Curran, C. (2002). A Delphi study to determine informatics competencies for Nurses at four levels of practice. Nursing Research, 51, 383-390.

The Ministry of Health of Turkey. (2010). Regalution of in-service education. Retrieved from www.saglik.gov.tr/TR/Yonlendir.aspx

Taşocak, G. (2012). Patient education. 3rd edn., Istanbul: Istanbul University Publications.

Turkish Linguistic Society. (2006). Anxiety. Dictionary of Turkish Linguistic Society. Retrieved from http://www.tdk.gov.tr/TR/SozBul

United Kingdom National Health Service Information Authority-NHS. (2010). European Computer Driving Licence (ECDL). Retrieved from htpp://www.connectingforhealth.nhs.uk/

Wishart, J., Ward, R. (2002). Individual differences in nurse and teacher training students' attitudes toward and use of information technology. Nurse Education Today, 22, 231-240. 